\title{
Evaluating the Effects of Public Transportation Networks on the Tourism Development of Hamadan Province
}

\author{
Faraneh Mashoufi \\ Master of Urban Planning, Tehran North Branch, Islamic Azad University, Tehran, Iran \\ Ali Sheikh Azami \\ Assistant Professor of Geography and Urban Planning Faculty of Marine Science \& Technology, North Tehran \\ Branch, Islamic Azad University, Tehran, Iran
}

\begin{abstract}
Nowadays, the transportation industry has played a major role in promoting the goals of countries. The impact of transportation on traveling and tourism is considerable since it is one of the factors affecting tourism growth and ultimately economic development. This research has been conducted aiming to evaluate the effects of transportation networks on the tourism development of Hamadan province. The methodology of the current study was a documentary research, survey (questionnaire), content analysis, and field observation. The statistical population of this research included the passengers who had stayed in the hotels and inns of Hamadan city in the first quarter of 2014.According to the statistics and figures obtained from Urban Information and Planning Organization of Hamadan Province, during these three months, 65,000 passengers had visited this city. The sample size consisted of 120 people who stayed in three hotels and were randomly selected as clustering to fill the questionnaires. The data of questionnaire was analyzed using SPSS software.According to the research findings, both hypotheses of the research were proved. According to the results of the research, the transportation industry had a significant role in the growth and development of tourism. The value of determination coefficient was 0.778 , which confirmed that $77.8 \%$ of the changes of dependent variable could be explained through independent variables. Moreover, one of the most influential factors in the development of tourism industry in Hamadan province wasroad transportation development. The significance level of test was obtained 0.000 .
\end{abstract}

Keyword: Public Transportation, Road Transportation, Tourism, Sustainable Development, Hamadan City

\section{Introduction}

Nowadays, the role and importance of infrastructures in the economic development of countries is not hidden for anyone. Meanwhile, transportation infrastructures are also of great importance, as appropriate transportation infrastructures form the foundation of the economic development of each territory and have a significant impact on other socio-economic and cultural activities. Today, the transportation industry plays a major role in advancing the goals of countries. Its importance has been promoted to the highest possible extent in countries that have emphasized the proper application of advanced and new systems. The economic aspects of transportation effects have been so much, the most significant of whichare attributed to the effect of transportation on labor division, profitability range, final price of goods and services, the emergence of savings resulted from scale, the expansion of economic competition, retail prices of goods, the emergence of Industrial and Tourism Poles and others.

Transportation and its effects on development as well as factors affecting the quality of transportation have been seriously considered in recent years by the urban managers and researchers of this field both at home and abroad. Vihova et al. (2005) have used a multi-layered fuzzy evaluation method that is a combination of a hierarchical approach and a comprehensive fuzzy assessment method to evaluate the various modes of BRT (Bus Rapid Transit). The criteria investigated in this research included socio-economic criteria, traffic-function factors, environmental impacts and fuel resources consumption. Bansio and Feloriya (2009) conducted a research on the support system of decision-making in urban transportation management using Multi- Criteria Decision Making (MCDM) method. The criteria of this research were consisted of the route geography, climatic conditions, traffic size, displacement capacity, average travel time, and the number of stops. Tozkaya (2009) using a fuzzy AHP multi-criteria decision-making method has investigated the environmental impacts on transportation methods. In this research, the rail, road, sea, and multimodal transportation options have been investigated using the transport and noise criteria, the potential for pollution dissemination reduction, the effects on wildlife, undesirable landscape, the use of energy resources, safety and seasonal conditions. 
Among domestic scholars, Nazari Tavakoli has investigated the status of transportation and tourism in the economy and the relationship between these two industries with each other. Sa'idi has addressed the issue of speed, its relationship with safety and solutions to manage it. The bad effects of high speed, sudden changes in speed and factors of speed selection by drivers are expressed in the form of 5 factors of road, traffic, human, environmental and technical factors, and the speed limitations enforcement, technical and engineering methods of traffic relaxation, supervision and enforcement of rules and regulations, training and promoting public culture level, and the use of smart technology have been introduced as solutions to control the speed in the roads.

Transportation is one of the main elements of the tourism industry, and the tourism industry is considered as one of the most important and profitable sources of the world at the beginning of the third millennium. The tourism industry in Iran in recent years has been futile due to the cultural, political, and lack of special attention by planners. While the development of this industry can be a good alternative to oil revenues. Essentially, the purpose of transportation system is the replacement of people and goods from one place to another acceptably, or the production of transportation services in accordance with the humans and goods replacement demands in a coordinated, comprehensive, integrated, safe, abundant, orderly, responsible, fast, easy and cheap manner. Additionally, the purpose of transportation is to realize profitability in the site or to create spatial desirability.This desirability is obtained when the products are transported from the origin to the consumption destinations and meet the needs of regions with the minimum cost. The impact of transportation on traveling and tourism is considerable and it is one of the factors impacting the tourism growth and ultimately economic development. In connection with the tourism topic, it should also be mentioned that tourism is proposed in various circles, especially economic and sometimes socio-cultural circles. As the most widespread service industry in the world, it has allocated a special place in the political, social, economic and cultural arenas to itself. Moreover, its positive impact is observed on the balance of payments, job creation, income generation and infrastructure development. The transportation structure, and the high quality and convenient access for tourists are the most important requirements for the creation of any tourism area. In most developed tourism areas, there is a wide and convenient transportation network.

Hamadan province is considered as one of the most important touristic poles of the country with its historical background and rich civilization and culture. Hamdi in a research has investigated historical-cultural tourism and urban sustainable development in Hamadan city. In other words, the effect of historical-cultural tourists' presence on the economic-physical, socio-cultural and environmental development changes in Hamadan has been investigated. Hamadan province with a population of 1,758,268 people and an area of 19,367,898 square kilometers (Statistics Center, 2011) has many tourism attractions. This province has road and air transportation networks, but its rail network has not been completed yet. Therefore, investment in transportation sector has a significant impact on tourism in the province and ultimately its economic development. As a result, in this article solutions are provided, even trivial, for the development of transportation networks and tourism promotion in Hamadan province, through evaluating the transportation networks of Hamadan province and its role on tourism development in the province, and investigating the weaknesses and strengths. The present research investigated two hypotheses that are going to be assessed through statistical analysis.

1) It seems that the most influential factor in the development of tourism industry in Hamadan province is the development of road transportation;

2) It seems that the tourism industry has a significant relationship with the development of public transportation in Hamadan province.

In the present research, the following questioned are answered: Is there a specific relationship between the development of transportation networks and tourism development? Is the transportation network in Hamadan province responding to tourism applicants? The general objectives pursued by this applied research include:

- Introducing the tourism industry as a worthwhile and considerable industry,

- Recognizing the relationship between the tourism industry and the transportation industry, and

- Providing solutions, programs and suggestions for the development and progress of the tourism industry in interaction with the transportation development.

\section{Research Method}

Three main approaches addressed in the methodology include positivist, interpretive, and critical approaches.

The main approach of this research was the positivist approach. Therefore, descriptive and explanatory survey should be used. Selection of the method was based on the subject and objectives of the research.

The methods used in this research included documentary study (use of books, dissertations, domestic and foreign articles, taking notes, and the internet), field observation and survey of descriptive and explanatory type. In terms of time criterion, this research was cross-sectional and in terms of depth criterion it was hidden. Hence, its data was collected using a questionnaire. In addition to the survey method, another method called content 
analysis (use of Statistics and Information of the Statistics Center of Iran, Cultural Heritage and Tourism Organization, and Ministry of Roads and Urban Planning) was also utilized in the current research.

Therefore, in the present research, in the section of subject literature, the library documents such as various types of books, articles and journals, scientific sites, government documents, official government publications, and statistic letters have been used. In the survey phase, a questionnaire or Likert scale has been used to collect data. It should be mentioned that these data were of a parametric type. The data has been analyzed through SPSS software. Exploratory factor analysis has been used to investigate empirical data in order to discover and identify the indicators as well as the relationship between them. The Kaiser-Meyer-Olkin (KMO) indicator and also the Bartlett Sphericity test have been used to investigate the sample size.

\subsection{Statistical Population, Sample Size and Sampling Method}

The statistical population was consisted ofa group of passengers who had visited Hamadan province in the timeframe of June 2014 from all over the country and had stayed in hotels. In the present research, the size of statistical population was not available, there was also a time constraint for the researcher, and the study methodology was descriptive and survey type, hence 120 people were selected as the minimum sample size. A cluster or group sampling has been used to select the sampling method. In the first stage, for selecting hotels among the Hamadan province, three hotels were selected randomly and through drawing.To do the research, 120 questionnaires were distributed in the selected hotels in Hamadan province.According to the Cochran formula, with regard to the population of passengers registered by the Management and Planning Organization of Hamadan Province (Statistic Yearbook of Hamadan Province, Spring 2014) and the Transportation and Road Maintenance Organization, 65,000 passengers had visitedHamadan during the first quarter of 2014. This number was entered to the Cochran formula to get the sample size.Number 116 was obtained as the result, but to avoid possible errors of the questionnaire, 4 numberswere added, that ultimately 120 people were selected. Then, randomly 40 people from the first hotel, 40 people from the second hotel, and 40 people from the third hotel were selected for the distribution of questionnaires.

\subsection{Validity and Reliability of the Questionnaire}

For the validity of research questionnaire, a pre-test method was used for 20 people, and in order to determine the reliability of questionnaire, 30 people were selected as the sample and the questionnaire was provided for them.Afterwards, the Cronbach's alpha method was used. This method was used to calculate the internal coordination of measurement tool that measures various attributes. If the Cronbach's alpha value was more than 0.7 , it could be said that the questions of questionnaire have sufficient validity and the coordination of questions is the same.

Table 1: Investigating Cronbach's Alpha

\begin{tabular}{|c|c|c|c|}
\hline Variable & Question & Number of Items & $\begin{array}{c}\text { Cronbach's Alpha } \\
\text { Coefficient }\end{array}$ \\
\hline The Whole Questionnaire & $1-49$ & 48 & 0.881 \\
\hline Transportation Indicator & $1-35$ & 34 & 0.817 \\
\hline Tourism Indicator & $36-49$ & 14 & 0.721 \\
\hline
\end{tabular}

According to the above table, all variables and the whole questionnaire had an alpha of more than 0.7 . Therefore, it could be concluded that the questions of questionnaire had sufficient validity and the coordination of the questions was the same.

\section{Research Framework}

\subsection{Relationship between Transportation Development and Tourism}

Studies performed by the World Organization emphasized that the transportation sector would bring about growth both nationally and globally, and would increase the contexts for access to national welfare and facilities. Moreover, the impact of transportation on tourism development was considerable. Nowadays, the development of tourism as the most profitable industry in the today's world is one of the main goals of planners, practitioners and authorities of governing states in most countries of the world. Increasing population, the advancement of science and technology, increasing free and leisure time, and many other factors have attracted the public's attention to the subject of tourism. Therefore, the experts of this industry, with regard to their specific knowledge and recognition, have acknowledged that tourism development without the progress and development of infrastructures and its elements is not possible at all. Therefore, there is a positive relationship between the quantitative and qualitative improvement of infrastructures and the number of tourists. The expansion and development of communication and modern means of transportation, development of airplanes and airport services, and utilization of appropriate relationship and communication routes (railway, train, and the like) would add to the tourist's interests in the destinations. The manner and quality of access infrastructures that are formed in the framework of communication routes and transportation means, is very important. The 
construction of large-scale transportation networks and highways, as well as the wide air transportation network, lead to the expansion of tourism (Papeli Yazdi, 2006, 129).

Transportation has many aspects. In a general classification, it can be divided into three parts of infrastructure, vehicles and utilization.

- Infrastructure: Includes transportation networks (roads, railways, airways, waterways, pipelines carrying materials, etc.) and nodes or terminals (such as airports, railway stations, bus station, ports).

- Vehicles: Generally they move in networks, such as cars, trains and airplanes.

- Utilization: Includes activities that control the system, such as traffic lights and clinometers, railway switches, air traffic control, and others.

But according to paragraph 2 of article 2 of the Trade Law, transportation has been divided into three parts:

- Marine Transportation

- Land or Draught Roads Transportation

- Air Transportation

In general, transportation methods can be separated into four modes of road, rail, water, and air transportation (Mahmudi, 2007, 24).

- Road Transportation: Road Transportation is formed by the combination of road with a vehicle specific for road and the driving force related to this vehicle.It is one of the most primitive forms of transportation used by human which still meets a major share of the transportation needs of communities. Motor vehicles related to roads have prominent advantages such as speed, flexibility in service delivery, the possibility of providing home-to-home service and easy ownership by individuals and the like.

-Rail Transportation: Although rail transportation, unlike road and water transportation, has not been rooted in the old history of human communities and has only been created after the European Industrial Revolution, currently it has gained a special place in the transportation system of the majority of countries, including developed and developing countriesin the world.

- Air Transportation: Air Transportation is the most advanced and fastest way for traveler and cargo transportation. At the present time, this mode of transportation makes access to various places in the world at a high speed and actualizes an intimate relationship between humans living all over the world within a few hours.

- Tourism: In the Moien Persian Dictionary tourism is defined as traveling to various countries and places to see, watch and have fun. In other words, tourism refers to a journey in which travelling to a destination is done and then it includes returning to the place of residence. In another place, tourism is the set of phenomena and connections caused by mutual actions among tourists, capitals, governments and host communities, universities and NGOs in the process of attracting, transporting, catering and controlling tourists and other visitors (Dinari, 2005, 46).

Although definitions differ in terms of classification, viewpoint, or purpose, there seems to be a common factor in all. Thus, it can be said that many of tourism analyses are based on principles that Burkhart and Medlik have presented as follows:

- Tourism is a combination of trends and communications;

- Two movement factors of travelling to destination and static staying are considered important in tourism;

- Tourism is an activity performed outside the place of residence and work place;

- The movement factor is short-time and its nature is considered temporary; and

- Visiting the destination is done for a variety of reasons, and its purpose is not to choose a permanent residence place or employment as an income creator factor (Rezvani, 2007, 20).

\subsection{Introducing Study Area: Hamadan Province}

The position of Hamadan province in Iran has been shown in figure 1. This province has been located in the southwestern part of Iran. It is adjacent to Zanjan province from the north, to Lorestan province from the south, to Markazi Province from the east, and to Kermanshah and Kurdistan provinces from the west. It has a cool climate with an area equal to 20,172 square kilometers; that is 1.2 percent of the country's total area. The population of this province in 2011 was equal to $1,758,268$ people.According to the latest country divisions, Hamadan province has 9 cities, 27 towns, 25 districts, 73 villages, and 1085 boroughs with inhabitants. The cities of this province are Hamadan, Tuyserkan, Asadabad, Bahar, Razan, Kabudarahang, Malayer, Nahavand, and Famenin. 


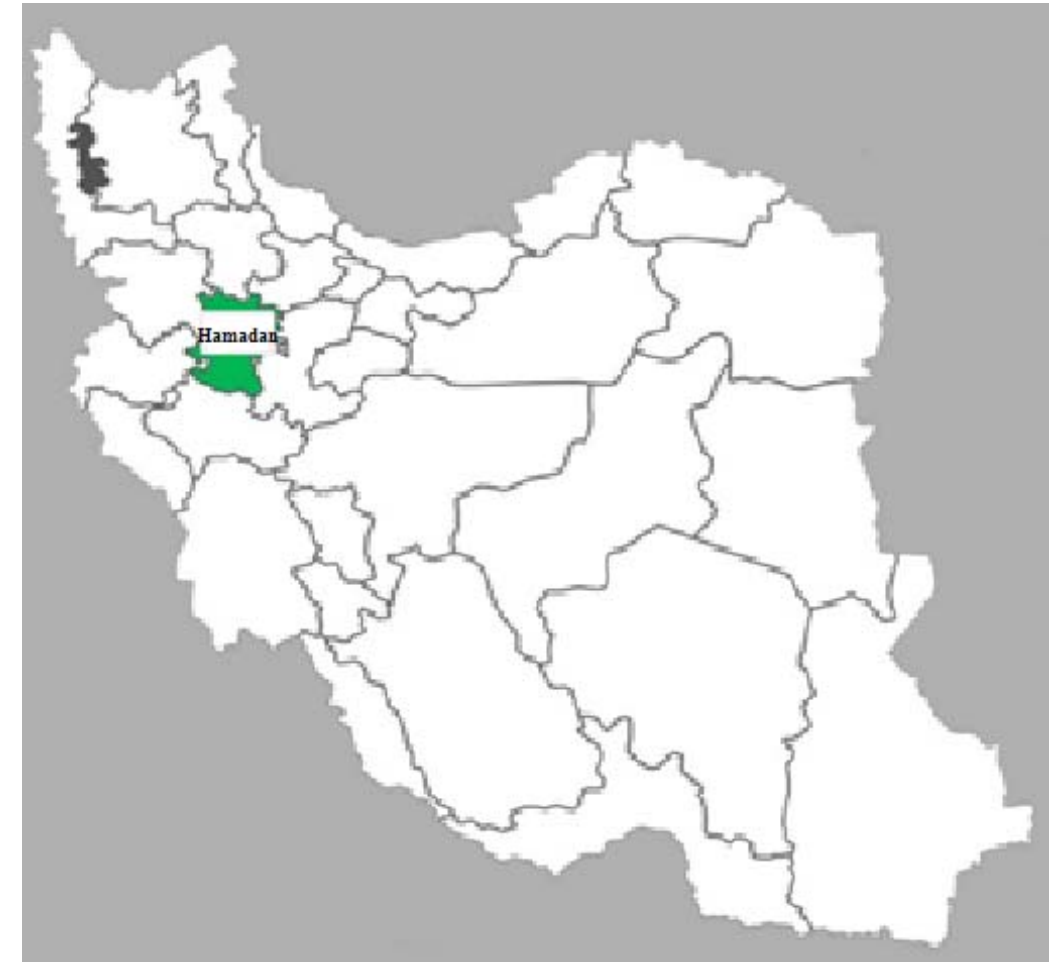

Figure 1: Geographical Location of Hamadan Province in Iran

\subsection{Characteristics of the Roads of Hamadan Province}

- Hamadan to Qazvin road towards the northeast with a length of 186 kilometers, whereby Hamadan is connected to the capital with a length of 337 kilometers,

- Hamadan to Asadabad road towards the southwest, with a length of 52 kilometers, whereby Hamadan is connected to the western cities of the country. In this way, Hamadan is connected to the city of Sanandaj (Kurdistan province center) with a length of 177 kilometers, and is connected to the city of Kermanshah (Kermanshah province center) with a length of 189 kilometers,

- Hamadan to Malayer road towards the southeast, with a length of 83 kilometers, whereby Hamadan is connected to the southern cities of the country.

The center of Hamadan province, i.e. Hamedan city has an airport (Bureau of Transportation Information and Statistics, 2007).

Table 2: Tourism Routes inside Hamadan Province (Kazemi, 2007, 56)

\begin{tabular}{|c|c|c|c|l|}
\hline No. & $\begin{array}{c}\text { Origin of } \\
\text { Travelling }\end{array}$ & $\begin{array}{c}\text { Destination } \\
\text { of Travelling }\end{array}$ & $\begin{array}{c}\text { Travelling } \\
\text { Route }\end{array}$ & \multicolumn{1}{c|}{ Attractions List } \\
\hline 1 & Hamadan & Lalejin & $\begin{array}{c}\text { Hamadan- } \\
\text { Ali Sadr } \\
\text { Cave-Lalejin }\end{array}$ & $\begin{array}{l}\text { Tomb of Baba Tahir, Alavian Dome, Natural History Museum, } \\
\text { Hagmatana Hill Museum, Hamadan Bazaar, Tomb of Esster } \\
\text { Mardkhai, Imam Square, Tomb of Avicenna, Nazari Garden } \\
\text { Museum, Qorban Tower, Shir-e-Sangi (Stone Lion), Abbas } \\
\text { Abad Complex, Ganjnameh Waterfall and Inscriptions, }\end{array}$ \\
\hline 2 & Hamadan & Nahavand & $\begin{array}{l}\text { Walnut Trees of Tuyserkan, Tomb of the Prophet Habaquq, } \\
\text { Mir Razi Ad-Din Tomb, Massoudi's Home, } \\
\text { Tuyserkan, } \\
\text { Nahavand }\end{array}$ & $\begin{array}{l}\text { Shaykh Abed Khan Zanganeh School, Emamzadeh Esmail } \\
\text { Zerhan, Farasfaj Caravanserai and Historic Bridge, Haj Agha } \\
\text { Torab Hamam (Persian Bath), Tomb of Baba Pireh, } \\
\text { Sarab Gamasiab, Sarab Giann, Sarab Malosan, }\end{array}$ \\
\hline 3 & Hamadan & Tuyserkan & $\begin{array}{c}\text { Hamadan, } \\
\text { Malayer, } \\
\text { Nahavand, } \\
\text { Tuyserkan }\end{array}$ & $\begin{array}{l}\text { Citadel and Fireplace of Noushijan, Sifineh Park, Lotfalian } \\
\text { Museum, Mir Fatah Ice-Pit }\end{array}$ \\
\hline
\end{tabular}




\subsection{Recognizing the Road Transportation Network of Hamadan Province}

In Hamadan province, the investments made in road transportation and the number of displaced passengers indicate people's welcoming of these means of transportation, in a way that the number of passengers displaced by bus from 4,792 thousand people in 1999 has increased to 7,358 thousand in 2005. The number of passengers arriving in the province by bus from 1,686,723 passengers has also increased to 3,070,165 passengers (Bureau of Transportation Information and Statistics, 2007).

\section{Highways and Freeways:}

Currently, about 511 kilometers of the connecting roads of Hamadan province are freeways and highways, which include $7 \%$ of the freeways and highways of the country. Nowadays, through the expansion of major connecting networks, 5 major cities of Hamadan province are connected to the center of the province, Hamadan city, through a highway and freeway, and the connection of four other cities is in progress.

The freeway of Hamadan-Saveh project, with a length of 175 kilometers was among the projects under construction in 2011.

The following routes are the main intercity roads of the city of Hamadan.

Tehran-Kermanshah-Khosravi Highway, in which Hamadan has 375 kilometersdistance from Tehran.

The main route of Tehran-Sanandaj, that Hamadan has 343 kilometersdistance from this route.

The main road of Tehran-Kermanshah-Ilam, that Hamadan is located in the same route.

The main route of Sanandaj-Hamadan, with a length of 182 kilometers,

The main road of Urmia-Kurdistan-Arak-Isfahan, that Hamadan is located in the same route.

Hamadan-Malayer Highway, with a length of 75 kilometers (Road Maintenance and Transportation Organization, 2009)

\section{Tehran to Hamadan Roads:}

Hamadan is located in the distance of 360 kilometers from the southwest of Tehran. Three routes of Tehran to Hamadan are as follows:

- The main route is the main road of Tehran-Hamadan, which passes through Qazvin, with a length of 341 kilometers, 200 kilometers of which is freeway and highway. This road passes through the Avaj Cervix.

- The road path of Saveh to Hamadan, which is about 50 kilometers shorter than the main route, this road is double sided and flat.

- The road that passes through Buin Zhahra,

\section{Hamadan Passenger Terminals:}

Hamadan has three passenger terminals.

- The Great Terminal of Hamadan is located on Ashura Square. This terminal has an area equal to 240,000 square meters. Service delivery of this terminal include all locations of the country (inside and outside of the province).

- Ekbatan Terminal located is on Ekbatan Street with an area of 15,170 square meters. Service delivery of this terminal is out-of-province;since2,500 to 3,000 passengers are displaced from this terminal every day.

- Blue White Terminal is located in Badia-Al-Zaman Hamadani Boulevard, with an area of 14,839 square meters. Service delivery of this terminal is within the province and 8,000 to10, 000 passengers are displaced from this terminal every day.

Hamadan province has shortages and weaknesses in terms of transportation networks, especially road transportation.There is a clearly felt need for completing and developing it in the future (Management and Planning Organization of Hamadan Province, 2004).

\subsection{Hamadan Province Air Transportation Network}

\section{Hamadan Airport:}

There is only one indoor airport located in Hamadan city, which covers the province's inland flights. This airport has been established in 1972 and has a band of 148 meters in width and 10,593 meters in length. Hamadan Airport is located at 5 kilometers of the north of the city and is considered among the old airports of the country.

\subsection{Hamadan Province Rail Transportation}

The conducted investigations indicated that Hamadan province has not been connected to the national railway network of the country so far and lacks any displacement by this way. While the railway of Khuzestan is passing through the southeast of province and is the nearest station to the province, the Arak station, is at the distance of 176 kilometers from the center of province. The railway construction project of Tehran-Hamadan-Sanandaj 
started in 2005.The railway length from Tehran to Hamadan is 267 kilometers and it is 151 kilometers from Hamadan to Sanandaj (Management and Planning Organization, 2005).

\section{Findings}

\subsection{Exploratory Factor Analysis, Bartlett Test, and KMO Indicator}

To calculate the weight of desired indicators, the principal components analysis technique was used to maximize the total squares of correlations.

Based on the results of Bartlett test and the KMO indicator, the KMO indicator value was equal to 0.871 . Since this value is close to 1 , so it can be said that the sample number (number of respondents) was sufficient for factor analysis. Also, the significance level value of the Bartlett test $(0.000)$ was less than 0.05 , which indicates that the factor analysis was appropriate for identifying the structure of factor model and the assumption of recognition of the correlation matrix was rejected.

Based on the results of factor analysis, the specific value of first factor, that is the road transportation, was obtained equal to 4.887, which is greater than all other factors (air transportation factor). Therefore, this factor had the highest effect and significance among the variables, and since the percentage of its specific value was equal to 35.723 , this factor had generally covered 35.723 percent of the population variances. One of the most important variables composing this factor included the safety of the road vehicle with a load factor of 0.821 .

\subsection{Determining the Communality Ratio of Variables with Factors}

The communality ratio represents the ratio of the variance of each of the variables that is common with other variables. In the post-rotation stage, this ratio represents the ratio of the variance of each variable that is explained by the extracted factors. The larger the extracted communality values, the better representative of the extracted factors. In the table below the communality ratio of the variables studied in the post-rotation stage have been presented.

Table 3: Communality Ratio of the Variables with the Post-Rotation Factors

\begin{tabular}{|l|c|}
\hline & Communality Ratio \\
\hline Road vehicle price & 0.604 \\
\hline Providing services (safety, health, security) travel by vehicle & 0.680 \\
\hline Safety of the road vehicle & 0.531 \\
\hline Timely departure of the road vehicle & 0.701 \\
\hline The speed of access to the destination by the road vehicle & 0.726 \\
\hline Providing funny services of road vehicle & 0.502 \\
\hline Number of the departure hours of journeys by road transportation means & 0.565 \\
\hline Accountability of the road transportation system to the demand of passengers & 0.718 \\
\hline Accountability of the road transportation network to the need of passengers & 0.504 \\
\hline Accountability of the air transportation system to the demand of passengers & 0.511 \\
\hline Safety in the road transportation means & 0.653 \\
\hline The status of road transportation means for traveling to and from province & 0.637 \\
\hline Safety in air transportation means & 0.890 \\
\hline The status of investment in the air transportation sector & 0.803 \\
\hline The status of air transportation means for traveling to and from province & 0.748 \\
\hline Hamadan province road access for tourists & 0.569 \\
\hline Hamadan province air access & 0.703 \\
\hline Access to passenger terminals in Hamadan province & 0.555 \\
\hline Access to Hamadan province airport & 0.848 \\
\hline
\end{tabular}

\subsection{Determining the Number of Factors}

Determination of the number of factors is performed based on Kaiser's criterion. Accordingly, the two factors, that their Initial Eigen Value was greater than one, were extracted. The factor analysis technique has categorized the variables included in the analysis into two factors, which explained $65.577 \%$ of the variance. The specific value and the explained variance percentage by each factor have been presented in the following table. 
Table 4: Specific Value and Explained Variance Percentage by Each Factor

\begin{tabular}{|c|c|c|c|}
\hline \multirow{2}{*}{ Factors } & \multicolumn{3}{|c|}{ Rotation Sums of Squared Loading } \\
\cline { 2 - 4 } & Specific Values & $\begin{array}{c}\text { Explained Variance } \\
\text { Percentage }\end{array}$ & $\begin{array}{c}\text { Explained Variance } \\
\text { Collective Percentage }\end{array}$ \\
\hline First Factor & 4.887 & 35.723 & 35.723 \\
\hline Second Factor & 4.140 & 28.790 & 64.513 \\
\hline
\end{tabular}

The specific value represents the contribution of each factor from the total variance of the variables, and the larger its value is; it indicates the greater importance of that factor. Based on the above table, the first factor with 35.723 percent has the highest share and the second factor with 28.790 percent has the lowest share in explaining total variables, and totally, the two mentioned factors could explain 64.513 percent of the total variance of the variables.

\subsection{Rotation of Variables}

In the present research, Varimax method with 3 rotations has been used. After the rotation stage, the variables that were related to each factor werespecified in a column. In fact, the variables that had more correlations with each other were located in one group. The results of variables rotation have been presented in the following table.

Table 5: Results of Rotation

\begin{tabular}{|c|c|c|c|}
\hline \multicolumn{2}{|l|}{ First Factor } & \multicolumn{2}{|l|}{ Second Factor } \\
\hline Variable & $\begin{array}{l}\text { Factor } \\
\text { Load }\end{array}$ & Variable & $\begin{array}{c}\text { Factor } \\
\text { Load }\end{array}$ \\
\hline Road vehicle price & 0.425 & $\begin{array}{l}\text { Accountability of the air transportation } \\
\text { system to the demand of passengers }\end{array}$ & 0.547 \\
\hline $\begin{array}{l}\text { Providing services (safety, health, } \\
\text { security) of travel by vehicle }\end{array}$ & 0.771 & Safety in air transportation means & 0.794 \\
\hline Safety of the road vehicle & 0.821 & $\begin{array}{l}\text { The status of investment in the air } \\
\text { transportation sector }\end{array}$ & 0.589 \\
\hline Timely departure of the road vehicle & 0.647 & $\begin{array}{l}\text { The status of air transportation means to } \\
\text { and from abroad }\end{array}$ & 0.684 \\
\hline $\begin{array}{l}\text { The speed of access to the destination by } \\
\text { the road vehicle }\end{array}$ & 0.635 & Air access of Hamadan province & 0.825 \\
\hline Providing funny services of road vehicle & 0.788 & Access to Hamadan province airport & 0.515 \\
\hline $\begin{array}{l}\text { Number of the departure hours of } \\
\text { journeys by road transportation means }\end{array}$ & 0.630 & & \\
\hline $\begin{array}{l}\text { Accountability of the road transportation } \\
\text { system to the demand of passengers }\end{array}$ & 0.548 & & \\
\hline $\begin{array}{l}\text { Accountability of the road transportation } \\
\text { network to the needs of passengers }\end{array}$ & 0.637 & & \\
\hline Safety in the road transportation means & 0.687 & & \\
\hline $\begin{array}{l}\text { The status of road transportation means } \\
\text { for traveling inside and from abroad }\end{array}$ & 0.596 & & \\
\hline $\begin{array}{l}\text { Hamadan province road access for } \\
\text { tourists }\end{array}$ & 0.504 & & \\
\hline $\begin{array}{l}\text { Access to passenger terminals of } \\
\text { Hamadan province }\end{array}$ & 0.715 & & \\
\hline
\end{tabular}

Accordingly, each of the extracted factors include the following variables:

\section{A: First Factor}

$\checkmark$ Road vehicle price

$\checkmark$ Providing services (safety, health, security) of travel by vehicle

$\checkmark$ Safety of the road vehicle

$\checkmark$ Timely departure of the road vehicle

$\checkmark$ The speed of access to the destination by the road vehicle

$\checkmark$ Providing funny services of road vehicle

$\checkmark \quad$ Number of the departure hours of journeys by road transportation means 
$\checkmark$ Accountability of the road transportation system to the demand of passengers

$\checkmark$ Accountability of the road transportation network to the needs of passengers

$\checkmark$ Safety in the road transportation means

$\checkmark$ The status of road transportation means for traveling inside and from abroad

$\checkmark$ Hamadan province road access for tourists

$\checkmark$ Access to passenger terminals in Hamadan province

Considering the above mentioned variables carefully, it is noticed that these factors have a specific feature in relation to ground transportation. This factor is called "Road Transportation".

Its specific value was 4.887 , which was greater than all other factors. Therefore, this factor had the highest effect and importance among the variables. Since the percentage of its specific value was equal to 35.723 , this factor had covered a total of 35.723 percent of the variances of population. One of the most important variables attributed to this factor was the safety of road vehicle with a load factor of 0.821 .

\section{B: The Second Factor}

$\checkmark$ Accountability of the air transportation system according to the demand of passengers

$\checkmark$ Safety in air transportation means

$\checkmark$ The status of investment in the air transportation sector

$\checkmark$ The status of air transportation means to and from abroad

$\checkmark$ Air access of Hamadan province

$\checkmark$ Access to Hamadan province airport

Considering the above mentioned variables carefully, it is noticed that these factors have a specific feature in relation to air transportation. This factor is called "Air Transportation".

\subsection{Investigating Research Hypotheses}

According to the obtained results of Kolmogorov-Smirnov test, Pearson correlation test has been used to investigate the research hypotheses and multiple linear regressions has been used to rank the variables.

First Hypothesis: It seems that the most influential factor in the development of tourism industry in Hamadan province is the development of road transportation.

For investigating the fitness of the regression model, road transportation and air transportation were considered as independent variables and the development of tourism industry was the dependent variable.

Table 6: Summary of Descriptive Results of Regression Model

\begin{tabular}{|c|c|c|c|c|c|}
\hline $\begin{array}{c}\text { Correlation } \\
\text { Coefficient }\end{array}$ & $\begin{array}{c}\text { Determination } \\
\text { Coefficient }\end{array}$ & $\begin{array}{c}\text { Adjusted Determination } \\
\text { Coefficient }\end{array}$ & $\begin{array}{c}\text { Durbin-Watson } \\
\text { Statistics }\end{array}$ & F Statistics & $\begin{array}{c}\text { Significance } \\
\text { Level }\end{array}$ \\
\hline 0.882 & 0.778 & 0.747 & 1.716 & 21.504 & 0.000 \\
\hline
\end{tabular}

Thus, as it is observed in the table, the Durbin-Watson value was located at the distance between 1.5 to 2.5 , so the assumption of the absence of correlation between errors was not rejected and regression could be used. Regarding the F statistic test value and its significance at confidence level of higher than $95 \%$, the regression equation is valid and its results can be analyzed. The determination coefficient value was 0.778 , which confirms that $77.8 \%$ of the changes of dependent variable can be explained by the aid of independent variables.

Table 7: Regression Analysis and Regression Coefficients

\begin{tabular}{|c|c|c|c|c|c|}
\hline Variable & B & $\begin{array}{c}\text { Standard } \\
\text { Error }\end{array}$ & $\begin{array}{c}\text { BETA (Beta Standardized } \\
\text { Coefficient) }\end{array}$ & T Statistics & $\begin{array}{c}\text { Significance } \\
\text { Level }\end{array}$ \\
\hline Fixed Number & 1.893 & 0.327 & - & 5.788 & 0.000 \\
\hline Road Transportation & 0.356 & 0.084 & 0.414 & 4.263 & 0.000 \\
\hline Air Transportation & 0.277 & 0.134 & 0.276 & 2.062 & 0.044 \\
\hline
\end{tabular}

According to the above table, it is observed that the significance level of independent variables was less than 0.05. Therefore, independent variables were entered into the regression model. Considering that the regression coefficient (B) was positive, it can be said that there was a positive and direct relationship with the development of tourism industry. Regarding the value of standardized beta coefficient, it can be said that the road transportation variable with the standardized beta coefficient (0.414) had the highest impact on the development of tourism industry and the air transportation variable with the standardized beta coefficient $(0.276)$ had the least impact on the development of tourism industry.

Second Hypothesis: It seems that the tourism industry has a significant relationship with the development of public transportation in Hamadan province. 
Table 8: Investigating Correlation Test

\begin{tabular}{|c|c|c|c|c|}
\hline \multicolumn{2}{|c|}{ Variable } & $\begin{array}{c}\text { Correlation } \\
\text { Coefficient }\end{array}$ & $\begin{array}{c}\text { Significance } \\
\text { Level }\end{array}$ & Result \\
\hline $\begin{array}{c}\text { Tourism } \\
\text { Industry }\end{array}$ & $\begin{array}{c}\text { Development of Public } \\
\text { Transportation }\end{array}$ & $0.651^{* *}$ & 0.000 & $\begin{array}{c}\text { sig. }<0.01 \text { There is a significant } \\
\text { relationship. }\end{array}$ \\
\hline
\end{tabular}

According to the above table, the significance level of test was 0.000 , which was less than 0.01 (the research error ratio is 0.01 ), so the zero hypothesis was rejected.Having $99 \%$ confidence, it could be stated that there was a significant relationship between the two variables. Regarding the positive value of correlation coefficient, it can be said that there was a positive correlation coefficient between the two variables of tourism industry and the development of public transportation, and the relationship of two variables wasdirect. In other words, increase one of them, would increase the next.

\section{Discussion and Conclusion}

According to research results, the transportation industry had a significant role in the growth and development of tourism. The determination coefficient value was 0.778 , the point that confirmedthat $77.8 \%$ of the changes of dependent variable could be explained by the aid of independent variables. Moreover, road transportation development was among the most influential factors in the development of tourism industry in Hamadan province. The significance level of test was obtained 0.000. As discussed, this research had two main questions: Is there a particular connection between the transportation industry and the tourism industry? It was specified that there was a significant, positive and direct relationship between these two variables, and the answer to this question has been through proving the second hypothesis of the research. The second question of research was whether the Hamadan province transportation network is responding to the needs of applicants or not? Through the factor analysis, it was concluded that road transportation was the most effective transportation method in Hamadan province on the tourism industry than air transportation. However, in recent years more investments have been made on road construction, but in the main axes, this program only helped the improvement of existing axes. A look at the growth of construction and exploitation of the country's roads shows that many crowded provincial and major distances do not have an efficient network of freight and passenger road transportation. The answer to this question has been obtained through the first hypothesis of research by using multiple regressions.

During the research, it was specified that in the transportation sector the main focus was still on road transportation facilities traditionally managed, and over the past two decades not that much changes has occurred in its management procedures. At the present time, the most important problem of road transportation is the fleet exhaustion on the one hand, and the increasing growth of driving accidents on the other.Since road transportation is responsible for replacing more than 90 percent of the load and passenger and the excessive use of personal cars for interurban journeys, it has made the roads arenas more tighter every day. Provided that no quick actions to improve this situation is performed, it is expected that the situation of this sector would be worsen.

\subsection{Solutions for Public Transportation Growth and Development}

Due to the fact that most transportation systems need much fund, such investments are only practicable by large organizations, or it sometimes becomes possible with the support of national organizations.

Therefore, in the transportation section of Hamadan province, the following suggestions are proposed:

\section{In the Air Transportation Sector:}

$\checkmark$ Increasing investment in the establishment of airports in Hamadan province;

$\checkmark$ Increasing the number of Hamadan airport flights to neighboring provinces;

$\checkmark$ Increasing flight hours;

$\checkmark$ Modifying the flight landing and airport slope of Hamadan to increase the number of arrival and departure flights;

$\checkmark$ Re-equipping airplanes and using updated technologies of the world require an expanded investment;

$\checkmark$ The government, by providing low-interest facilities to the private sector and encouraging them to invest, can enter safe, high-quality and modern aircrafts to the country's airlines;

$\checkmark$ Lowering the percentage of flights delay;

$\checkmark$ Thinking about special measures and having specific plans when airports are faced with crowded population;

$\checkmark$ Reducing the price of flight tickets for the province tourism passengers to encourage passengers to travel to the province;

$\checkmark \quad$ Increasing travel and tourism agencies.

\section{In the Rail Transportation Sector:}


$\checkmark$ Completion of the Hamadan province railroad network project and connecting it to the railways of the country;

$\checkmark$ Development of rail network between cities;

$\checkmark$ Increasing domestic and foreign investment in railway and stations development and equipping them.

In the Road Transportation Section:

$\checkmark$ Strengthening the cargo and bus road transportation companies of Hamadan province;

$\checkmark$ The development of asphalted roads for some of the country's tourism and ecotourism places that lack road;

$\checkmark$ Making the highly traffic routes and main routes double-sided;

$\checkmark$ Improving the quality level of Hamadan province roads;

$\checkmark$ Construction of residential and recreational complexes between the routes;

$\checkmark$ Equipping the fleet of road transportation to modern and new model buses and minibuses

$\checkmark \quad$ Increasing and developing travel terminals at the provincial level;

$\checkmark$ Reducing the price of Hamadan province tourism tickets for travel to the province when the number of passenger is low;

$\checkmark$ Increasing the services of the provincial road transportation fleet during the holidays and in highly demand days.

\section{In the Tourism Sector:}

Considering the existing tourism potential in Hamadan and the lack of appropriate facilities and infrastructures, it is essential for the institutions and agencies responsible in this regard to form permanent committee for accommodating travelers by precise and coordinated planning. Therefore, the following suggestions can be proposed:

$\checkmark$ Increasing the number of hotels, inns and residential centers

$\checkmark$ Increasing the reception capacity of province hotels by investment and providing public facilities

$\checkmark$ Reducing the cost of accommodation for travelers in residential centers

$\checkmark$ Developing tourism travel agencies of the province and holding tourism tours to the province

$\checkmark$ Preservation and maintenance of historical, religious, and tourism monuments of the province

$\checkmark$ Setting up temporary committees on summer and feast holidays for accommodating travelers.

\section{References and Resources}

[1] Afshari, Zahra (2008), "Economic Planning", Tehran, Publication of Samt, Fourth Edition

[2] Management and Planning Organization, (2005), "Five Years Economic, Social and Cultural Development Program of Hamadan Province in 2000-2004", Tehran

[3] Papeli Yazdi, Mohammad, (2006), "Iran Tourism”, Publication of Samt, First Edition

[4] Sa'idi, Mohammad Mehdi (2010), "Speed, Main Challenge of Road Transportation Safety”, Master Thesis, Islamic Azad University, Isfahan Unit

[5] Hamdi, Karim (2009), "Investigating Historical-Cultural Tourism on Hamadan City Sustainable Development", Master Thesis, Payame Noor University of Mashhad

[6] Management and Planning Organization of Hamadan Province, Statistical Yearbook of Hamadan Province, 2004

[7] Road Maintenance and Transportation Organization (2009), "Statistical Yearbook, Planning Deputy, Office of Information Technology, Road Maintenance and Transportation Organization

[8] Transportation Information and Statistics Bureau (2007), "The Share of Various Transportation Sectors in Cargo and Passenger Displacement during the Years 2002-2008”, Ministry of Road and Transportation, Deputy of Planning and Transportation Economy

[9] Dinari, Ahmad (2005), "Urban Tourism in Iran and the World" Mashhad, Publication of Vazhgan Kherad

[10] Rezvani, Ali Asghar, (2007), "Geography and Tourism Industry", Tehran, Payame Noor University Publication

[11] Kazemi, Mahdi, (2007), "Tourism Management", Publication of Samt, Second Edition

[12] Mahmoudi, Ali (2007), "Transportation Economy", Tehran, Institute for Business Studies and Researches

[13] Nazari Tavakoli, Samira (2007), "Investigating the Position of Rail Transportation on Tourism Development in Khorasan Razavi Province", Master Thesis in Economics, Faculty of Economics and Accounting, Islamic Azad University, Central Tehran Unit.

[14] Arahi, Yetal, 2006, Rural tourism in Japan, The integration of rural communities researcher.

[15] Chang, Peter.R, 2007, Tourism Management, Nova Science Publisher. 